\title{
Ophthalmomyiasis and Basal Cell Carcinoma: A Case Report
}

\author{
Mohammad Yasin ${ }^{1, *}$; Amirhossein Moghhtader Mojhdehi ${ }^{1}$; Mehrdad Haghighi ${ }^{1}$; Kamran \\ Akbarzadeh $^{2}$ \\ ${ }^{1}$ Department of Infectious Diseases, Imam Hussein Teaching and Medical Hospital, Shahid Beheshti University of Medical Sciences, Tehran, IR Iran \\ 2 Departmentof Medical Entomology and Vector Control, School of Public Health, Tehran University of Medical Sciences, Tehran, IR Iran \\ *Corresponding author: Mohammad Yasin, Department of Infectious Diseases, Imam Hussein Teaching and Medical Hospital, Shahid Beheshti University of Medical Sciences, \\ Tehran, IR Iran. Tel: +98-2173432338, Fax: +98-2177557069, E-mail: mohammadyassin@ymail.com
}

Received: March 3, 2013; Revised: April 16, 2013; Accepted: May 20, 2013

Introduction: Ophthalmomyiasis is a rare disorder that is caused by invasion of dipterous larvae to necrotic tissues.

Case Presentation: An 80-year-old woman with invasive basal cell carcinoma (BCC) presented anabnormal growth of worm in her eye. She had ophthalmomyiasis caused by Lucilia sericata larva in here nucleated eye. L. sericata is common all over the temperate and tropical regions, mainly in the southern hemisphere, particularly in Africa and Australia.

Discussion: Immunocompromised patients with diabetes, malignancies, and patients undergoing immunosuppressive therapy are at high risk of ophthalmomyiasis. In addition, aggressive treatment is needed to prevent the secondary infections.

Keywords: Screw Worm Infection; Ectoparasitic Infestations; Myiasis; lucifensin

\section{Introduction}

Myiasis is a parasitic infestation of mucosal membranes and skin by Dipterus larvae (1). Myiasis is classified based on many factors such as the location of larvae embedded, causative agents and relationship between the host and the parasite $(2,3)$. Based on the infestation location, it is categorized into cutaneous, subcutaneous, cavitary, intestinal, urinary and vaginal (4). Many cases of myiasis have been reported in different countries (5), the reported cases in Iran are summarized in Table 1(6). Ocular involvement by larvae is known as ophthalmomyiasis (7) and is classified into external (infestation of conjunctiva and/or eyelid) and internal (the globe is invaded)(8). Usually ophthalmomyiasis is caused by larvae of sheep nose botfly (Oestrus ovis) and less commonly by human botfly (Dermatobia hominis) (9) and the head and neck ophthalmomyiasis is rare world widely (10), which was first described in 1900 by Kert (1). Immunocompromised patients with malignancies, diabetes and patients undergo immunosuppressive therapy, trauma and skin lesions are considered to be the risk factors of ophthalmomyiasis, however; there are few case reports about the infestation in healthy individuals (11).
Table 1. Reports of Human Myiasis Cases and Dipteran Species From Iran

\begin{tabular}{ll}
\hline Types of Myiasis & Causative Agent \\
\hline Auricular & $\begin{array}{l}\text { Chrysomya bezziana, Sarcophaga } \\
\text { haemorrrhoidalis }\end{array}$ \\
\hline Gingival & Wohlfahrtia magnifica \\
\hline Head skin & Chrysomya bezziana \\
\hline Nasal & Erista listenax \\
\hline Ocular & Oestru sovis \\
\hline Oral mucosa & Oestru sovis, Lucilia sericata \\
\hline Urogenital & Chrysomya bezziana \\
\hline Pharyngeal & not specified \\
\hline
\end{tabular}

\section{Case Presentation}

An 80-year-old woman residing in Tehran with invasive basal cell carcinoma (BCC), who had a history of expanded lesions in her right eye and removal of her right globe, and diabetes mellitus, was admitted to emergency department (ED) because of abnormal growth of some kind of worms in her right orbit. She mentioned that 10

Implication for health policy/practice/research/medical education:

This study could be applicable in determining the risk factors for ophthalmomyiasis and cavitary myiasis and their proper treatments.

Copyright (C) 2013, Infectious Diseases and Tropical Medicine Research Center. This is an open-access article distributed under the terms of the Creative Commons Attribution License, which permits unrestricted use, distribution, and reproduction in any medium, provided the original work is properly cited. 
Yasin M et al.

days before admission, she developed foreign body sensation in her right orbit and around her nose (Figure 1). The patient's nephew noticed some movements in her eye and brought her to ED. Close examination of the patient's eyes demonstrated larvae movements inside the eye cavity. The larvae were white, wriggling, and about 8 * $2 \mathrm{~mm}$ in diameter. The patient received Diphtheria and tetanus toxoids (DT) vaccine (0.5 $\mathrm{mg} / \mathrm{IM})$ and tetabulin immunoglobulin (500 mg/IM), and three larvae were collected and sent to the parasitology department for further investigations. Brain CT scan was performed without IV contrast, which revealed the enlargement of right extraocular muscles that caused severe pressure on the globe and optic nerves, was associated with destruction of the soft tissue around the zygomatic part of maxillary bone, expansion and probably destruction of small sites of bone, and the secondary sinusitis. Sinus and pharynx endoscopies were performed to remove the larvae. The blood samples were collected for CBC, blood culture, biochemistry, liver function tests and lipid profile analysis (the results are shown in the Table 2). Antibiotic therapy with vancomycin (500 $\mathrm{mg} / \mathrm{BD} / \mathrm{IV})$, and meropenem (1 $\mathrm{g}$ $\mathrm{BD} / \mathrm{IV}$ ) was administered, and there placement of the eye dressing performed every eight hours. After controlling the patient was discharged with weekly follow-ups.

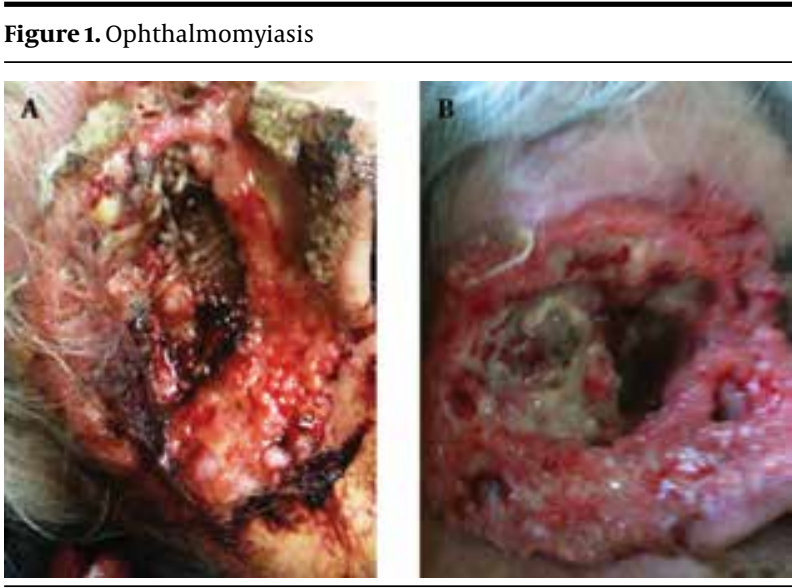

A) before treatment; B) after treatment.

Table 2. CBC and Blood Culture Results

\begin{tabular}{ll}
\hline Test & Result \\
\hline WBC & $9900 / \mu \mathrm{L}$ \\
\hline RBC & $3.81 \mathrm{~mL} / \mu \mathrm{L}$ \\
Hemoglobin & $11.2 \mathrm{~g} / \mathrm{dL}$ \\
Platelet & $285000 / \mu \mathrm{L}$ \\
\hline Blood culture & Staphylococcus aureus \\
\hline Antibiogram & \\
\hline Sensitive & $\begin{array}{l}\text { Gentamycin, oxacillin, vancomycin, } \\
\text { tetracycline }\end{array}$ \\
\hline Resistance & Erythromycin \\
\hline
\end{tabular}

\section{Discussion}

Many families of the order Diptera cause human and animal myiasis including (4) oestrus (botfly), Calliphoridae (screwworm and blowfly) and Sarchophagidae (carrion feeding). Myiasis is more prevalent among males especially those younger than 50 years old (12). Ophthalmomyiasis is usually caused by Oestrus ovis, and less commonly by Dermatobiahominis, and very rarely by $L$. sericata (9). Generally, these flies do not parasitize the hosts, they just lay their eggs in necrotic tissues, corpses and open wounds especially in animals, therefore, humans are the accidental hosts and trauma is known as an important risk factor (13). L. sericata is found in the tropical regions and it prefers humid and warm weather, therefore, it can be found around coastland dry regions (14). The presence of the three bristles on the dorsal mesothorax is the most common characteristic of $L$. sericata, which has similarity with another species called L. cuprina. It is important to identify the right causing Lucilia, two features are used to differentiate these two species, one of them is the color of the first pair of legs, L. sericata has blue - black one, while L. cuprina has metallic green pairs, the second feature is the occipital setae which is $6-8$ bristles on each side and only one in L. sericata and L. cuprina, respectively (14). A single female typically produces 2000 - 3000 eggs during its life, and occasionally in every batch, it lays about 150 - 200 eggs, depending on the environment and temperature, it takes about 8-10 hours in warm and three days in cooler weather to hatch out. The infestation occurs when the female put her eggs in infected wounds, and the larvae feed on dead and necrotic tissues (15, 16). Even though infestations of all flies are common in tropical regions, ophthalmomyiasis is comprised about $5 \%$ of all cases (17). Ophthalmomyiasis has nonspecific symptoms such as burning, pain, itching, and foreign body sensation (18). The treatment of all types of ophthalmomyiasis is directed on removing the larvae and surgical debridement to prevent secondary infections and should be followed closely $(2,9,10)$.

\section{Acknowledgements}

We thank Dr. Eshaghi for his help, and we also thank all the parasitology staff for their precious helps.

\section{Financial disclosure}

There was no financial disclosure.

\section{Funding/support}

There was no funding or support from any kind.

\section{Authors' contribution}

Design of the study, scientific collection of information, drafting the paper and reviewing and approving the final 
version: Mohammad Yasin, Amirhossein Moghhtader Mojhdehi, Mehrdad Haghighi. Parasitological analysis: Kamran Akbarzadeh.

\section{References}

1. Sivaramasubramanyam P, Sadanand AV. Opthalmomyiasis. Br J Ophthalmol.1968;52:52-65.

2. Maier H, Honigsmann H. Furuncular myiasis caused by Dermatobia hominis, the human botfly. J Am Acad Dermatol. 2004;50(2 Suppl):S26-30.

3. Burns DA. Diseases caused by arthropods and other noxious animals. In: Burns T, Breathnach S, Cox N, Griffiths C editors. Rook's textbook of dermatology. 7 ed. Oxford: Blackwell Science Ltd.; 2004. p. $33.8-11$.

4. Bennett JE, Douglas RG, Mandell GL. Infectious diseases and their etiologic agents. In: Bennett JE, Douglas RG, Mandell GL editors. Principles and practice of infectious diseases. 7 ed. Philadelphia: Churchill Livingstone; 2000. pp. 3667-9.

5. James MT. The flies that cause Myiasis in man. U.S. Department of Agriculture; 1947.

6. Babamahmoudi F, Rafinejhad J, Enayati A. Nasal myiasis due to Lucilia sericata (Meigen, 1826) from Iran: a case report. Trop Biomed. 2012;29(1):175-9.

7. Wilhelmus KR. Myiasis palpebrarum. Am J Ophthalmol. 1986;101(4):496-8.

8. Mohsen M, Keramatalab H. External ophthalmomyiasis caused by sheep botfly (Oestrus ovis) larvae: a report of 8 cases. Arch Iran Med. 2004;7:136-139.
9. Reingold WJ, Robin JB, Leipa D, Kondra L, Schanzlin DJ, Smith RE. Oestrus ovis ophthalmomyiasis externa. Am J Ophthalmol. 1984;97(1):7-10.

10. Balasubramanya R, Pushker N, Bajaj MS, Rani A. Massive orbital and ocular invasion in ophthalmomyiasis. Can J Ophthalmol. 2003;38(4):297-8

11. Sachdev MS, Kumar H, Roop, Jain AK, Arora R, Dada VK. Destructive ocular myiasis in a noncompromised host. Indian J Ophthalmol. 1990;38(4):184-6.

12. Marquez AT, Mattos Mda S, Nascimento SB. [Myiasis associated with some socioeconomic factors in five urban areas of the State of Rio de Janeiro]. Rev Soc Bras Med Trop. 2007;40(2):175-80.

13. Puthran $\mathrm{N}$, Hegde $\mathrm{V}$, Anupama B, Andrew S. Ivermectin treatment for massive orbital myiasis in an empty socket with concomitant scalp pediculosis. Indian J Ophthalmol. 2012;60(3):225-7.

14. Bishop D. Variations in numbers of occipital setae for two species of Lucilia (Diptera: Calliphoridae) in New Zealand. New Zeal Entomol.1991;14:29-31.

15. Australian Museum: Development times of Lucilia sericata at different temperatures. Corpse fauna page. Available from: http:/l edis.ifas.ufl.edu/pdffiles/IN/IN90300.pdf.

16. Cetinkaya M, Ozkan H, Koksal N, Coskun SZ, Hacimustafaoglu M, Girisgin O. Neonatal myiasis: a case report. Turk J Pediatr. 2008;50(6):581-4

17. Jain A, Desai RU, Ehrlich J. Fulminant orbital myiasis in the developed world. BrJ Ophthalmol. 2007;91(11):1565-6.

18. Masoodi M, Hosseini K. The respiratory and allergic manifestations of human myiasis caused by larvae of the sheep bot fly (Oestrus ovis): a report of 33 pharyngeal cases from southern Iran. Ann Trop Med Parasitol. 2003;97(1):75-81. 